\title{
Dietary Polyphenols and Periodontitis-A Mini-Review of Literature
}

\author{
Arpita Basu ${ }^{1, *}$, Emily Masek ${ }^{1}$ and Jeffrey L. Ebersole 2 (iD) \\ 1 Department of Kinesiology and Nutrition Sciences, School of Allied Health Sciences, \\ University of Nevada Las Vegas, 4505 S Maryland Parkway, Las Vegas, NV 89154, USA; \\ masek@unlv.nevada.edu \\ 2 Department of Biomedical Sciences, School of Dental Medicine, University of Nevada Las Vegas, \\ Las Vegas, NV 89154, USA; jeffrey.ebersole@unlv.edu \\ * Correspondence: arpita.basu@unlv.edu; Tel.: +1-702-895-4576
}

Academic Editor: Margarida Castell Escuer

Received: 10 June 2018; Accepted: 18 July 2018; Published: 20 July 2018

\begin{abstract}
Periodontitis, which is a chronic infection and disease of the periodontium, is a significant global health burden and is linked to other chronic health conditions such as diabetes and cardiovascular diseases. Dietary polyphenols present in a wide variety of plant-based foods, herbs, and botanicals have been shown to exert antimicrobial, anti-inflammatory, and reduced osteoclast and alveolar bone loss activities in animal models of periodontitis. Polyphenol-containing beverages and foods especially green tea and its active catechin epigallocatechin-3-gallate, cranberries, pomegranates, and fruit and vegetable extracts have reported bacteriostatic/bactericidal activity against microbial species such as $P$. gingivalis and shown total bacterial burden in clinical studies. These polyphenols also exhibit anti-inflammatory and antioxidant effects, which have the potential to impact various biological mechanisms for reducing the initiation and progression of periodontitis. The main objective of this mini-review is to focus on the mechanisms of action of dietary polyphenols in improving the pathophysiology underlying chronic inflammatory diseases like periodontitis based on pre-clinical and clinical models.
\end{abstract}

Keywords: periodontitis; polyphenols; green tea; inflammation; P. gingivalis

\section{Introduction}

Two of the most prevalent forms of oral conditions are dental plaque-induced gingivitis and chronic periodontitis. Based on the National Health and Nutrition Examination Survey (NHANES) (2009-2012), approximately 50\% of US adults greater than 30 years old exhibit periodontitis with Hispanics, non-Hispanic Blacks, and aging individuals disproportionately affected by this condition [1]. In this previous cross-sectional study, periodontitis was defined by combining measures of clinical attachment loss (AL) and periodontal probing depth (PD) on all teeth except third molars, which is defined by the American Academy of Periodontology [2]. Based on the Global Burden of Disease 2010 study, severe periodontitis is a significant global health burden and represents the sixth most prevalent condition worldwide. It affects approximately 743 million people worldwide [3] Periodontitis is a localized inflammatory process mediating the destruction of soft and hard periodontal tissues triggered by a complex bacterial biofilm insult. Poor dental behaviors and oral hygiene have been determined to be the primary factors in disease risk and expression and are associated with many dietary and lifestyle factors as well as the concomitant presence of chronic systemic conditions such as diabetes [4]. Based upon the disruption of the oral epithelial barrier, periodontitis is also characterized by systemic inflammatory host responses that may contribute to the higher risk of cardiovascular disease (CVD) 
among affected patients [5]. Several reports consistently demonstrate a positive correlation between periodontitis and vascular diseases including reports about diabetes [6-9]. Microbial translocation from periodontal lesions and resulting systemic inflammation are considered common links that underlie these associated conditions with elevated systemic inflammation determined by biomarkers such as the C-reactive protein and pro-inflammatory cytokines and chemokines correlated to periodontitis $[10,11]$. These observational data identify the need for optimal oral health as an integral component for the prevention and management of chronic conditions such as CVD and diabetes. Dietary nutrients and specific bioactive compounds including polyphenols have emerged as influential factors in the etiology and progression of periodontitis. In recent years, observational studies show a strong correlation between the intake of fruits and vegetables and other antioxidant nutrients with oral health-related quality of life in adults $[12,13]$. These effects have been mainly attributed to their function in reducing oxidative stress, inflammation, and replacing less healthy dietary choices that promote increased bacterial burden and associated inflammation. Nutritional studies are now recognizing the role of food groups high in vitamin $\mathrm{C}$ and other compounds such as the anti-inflammatory omega-3-fatty acids and fiber in decreasing the risks of periodontitis $[4,14,15]$. While these reports are promising, further research deserves urgent attention given the high prevalence of periodontitis in the US and global population. Given the lack of reviews in this area of research, the primary objective of this focused narrative is to review and discuss the salient findings of reported nutritional studies in recent years. This paper outlines the role of dietary polyphenols in periodontitis.

\section{Dietary Polyphenols: Link with Chronic Diseases and Periodontitis}

Dietary polyphenols from commonly consumed foods and beverages as well as herbs and botanicals are well known for their anti-microbial, antioxidant, and anti-inflammatory functions. Dietary polyphenols can be broadly grouped into many different categories. These categories include tannins, flavonoids, and lignin-carbohydrate complexes (LCC), which have been associated with anti-microbial and anti-inflammatory properties in mechanistic studies [16], as well as those that are commonly consumed as dietary sources. For example, 437 polyphenol compounds were identified in raw and prepared foods in a newly established database for European countries [17]. Among these, the dietary flavonoids and their sub-classes (anthocyanidins, flavones, flavan-3-ols, flavonols, and flavanones) have been widely studied for their associations with chronic diseases including those related to inflammation [18-20]. Epidemiological and clinical studies over the last decade have accumulated substantial evidence about the inverse associations of dietary polyphenol intake especially the flavonoids found in fruits, tea, and olives with a risk for several chronic diseases such as diabetes [21], cardiovascular diseases [19], cancer [22], and neurodegenerative diseases [20]. Based on the emerging relationship of these conditions with periodontitis $[23,24]$, studying a potential causal link of dietary polyphenols in lowering the risks of periodontitis is a critical research direction. Green tea, which is a rich source of flavonoids such as catechins, have been shown to exert significant antioxidant and bactericidal activities in small clinical trials when participants consumed green tea supplements [25] or slow release strips of green tea catechins mechanically applied into dental pockets [25]. A recent paper reviewed the role of dietary polyphenols in oral health and identified the anti-viral and anti-inflammatory effects of polyphenols derived from green tea and black tea. The paper also identified licorice root as topical agents that can be applied directly to the oral cavity [16]. Based on the results from various experimental models and clinical studies, designing polyphenol formulations into local delivery applications may present an emerging line of natural therapy for periodontitis and may maximize improved oral health among more populations.

\section{Dietary Polyphenols and Periodontitis: Cellular Studies}

Many in vitro studies have examined the effects of dietary polyphenols on inflammatory markers and pathogenicity of bacteria associated with periodontitis (Table 1). A variety of microorganisms have been detected in dental biofilms and in periodontopathic biofilms. These bacteria include Porphyromonas 
gingivalis, Tannerella forsythia, Treponema denticola, and A. actinomycetemcomitans [26]. However, recent microbiome studies have suggested the contribution of other periodontopathogens [23]. Dietary sources of polyphenols including curcumin, green tea, and pomegranates have been identified for their potential role in treating inflammatory responses of gingival and periodontal diseases. Using a comprehensive in vitro assay, Shahzad et al. screened 48 polyphenolic compounds for their role in inhibiting periodontal pathogens including the major categories of polyphenols such as organic acids (hydroxybenzoic acids, hydroxycinnamic acids, hydroxyphenylacetic acids), flavanols, flavanones, anthocyanins, flavones, isoflavonoids, and phenolics. When applied to bacterial strains implicated in periodontitis, it was observed that the curcumin was the most potent inhibitor of bacterial growth. This was followed by pyrogallol, pyrocatechol, and quercetin [26]. Notably, these polyphenol treatments were demonstrated to selectively target pathogenic biofilm microorganisms especially $P$. gingivalis while sparing normal microbiota members of the dental biofilm such as Streptococcus mitis [26]. The viability, proliferation, and biofilm-forming capacity of pathogens associated with periodontitis can be significantly affected by dietary polyphenols. Other commonly consumed dietary sources of polyphenols, such as blueberry extract and tea polyphenols (black and green tea extracts and theaflavins) have also been shown to inhibit biofilm formation and slow bacterial growth in several studies [26-28]. The addition of epigallocatechin-3-gallate (EGCG), which is the most abundant and bioactive green tea polyphenol, and green tea extract to a culture of human gingival epithelial cells inhibited the release of several cytokines [29].

Less commonly used herbal extracts such as common sorrel and Limonium brasiliense extracts were shown to reduce the adherence of $P$. gingivalis to human gingival fibroblast cells. The mechanism has been explained to be the potential interaction of polyphenols with protein complexes called gingipains [30,31]. Polyphenols have also been demonstrated to exert antioxidant properties and inhibit the release of inflammatory cytokines in vitro [29]. The use of resveratrol, which is a phenolic compound in grapes and wine, reduced nitric oxide expression in a dose-dependent and time-dependent manner in human periodontal ligament cells exposed to P. gingivalis [32]. These promising in vitro effects of the polyphenols in altering various responses that could contribute to pathological changes in periodontitis deserve extended investigations using animal models and human clinical studies.

\section{Dietary Polyphenols and Periodontitis: Animal Studies}

A limited number of in vivo studies using rodent models have provided mechanistic data on the role of dietary polyphenols in alleviating features of periodontitis (Table 3). Polyphenol treatment of animal disease models has shown to decrease inflammatory markers and macroscopic damage associated with periodontal disease [33-36]. Oral intake of EGCG and curcumin was observed to lower circulating levels of inflammatory cytokines known as IL- $1 \beta$, TNF- $\alpha$, and IL-17, which are implicated in the inflammation and disease progression of periodontitis [33,34]. Animal studies using St. John's wort (Hypericum perforatum) and green tea extract found that these treatments reduced the extant of bacteria-induced immune cell infiltration into the periodontal tissues, which could help mitigate further inflammatory damage $[35,36]$.

Animal studies have also specifically documented the effects of polyphenol treatment on alveolar bone loss. Alveolar bone resorption is a hallmark of periodontitis due to the deleterious effects of inflammatory cytokines on osteoclast numbers, maturation, and function. Osteoclastogenesis is excessively stimulated during the inflammatory process. The resulting dysregulation of bone formation and resorption due to the surplus of active osteoclasts dissolves the mineral matrix of the bone [37]. Oral intake of myricetin, which is a polyphenol derived from many plant foods, was observed to reduce alveolar bone loss in mice by interacting with osteoclast-related genes at doses of $10 \mu \mathrm{M}$ and $50 \mu \mathrm{M}$ concentrations [37]. Similar results have also been demonstrated following treatment with mangiferin, which is a polyphenol present in mangos, at $50 \mathrm{mg} / \mathrm{kg}$. This revealed reduced bone loss in mice with decreased levels of IL- 6 and IL- $1 \beta$, which directly interact with the osteoclastogenic 
pathways and promote the maturation of osteoprogenitor cells into mature osteoclasts [38]. Resveratrol and curcumin treatment also demonstrated amelioration of bone loss in rats using antioxidants and reducing inflammatory cytokines at doses of $10 \mathrm{mg} / \mathrm{kg}$ and $100 \mathrm{mg} / \mathrm{kg}$, respectively [34].

An important point to consider is the limited physiological relevance of the large polyphenol doses used in cell and animal studies. In most cases, dietary polyphenols have poor bioavailability in humans and undergo rapid metabolism and excretion. For example, feeding studies have shown consumption of $100 \mathrm{~g}$ dietary berries lead to concentrations of serum quercetin, which is a common dietary polyphenol that ranges from 15-25 $\mu \mathrm{M}$ in middle-aged adults [39]. Similarly, studies have reported non-detectable or very low levels of curcumin in clinical trials after a large dose intervention ( 8 g curcumin/day) [40]. Therefore, while the pre-clinical data are intriguing, further studies are needed at habitual levels of intake in human clinical trials of periodontitis. These actions of dietary polyphenols in animal models of periodontitis provide consistent support for increasing exposure to common sources of dietary polyphenols such as curcumin, fruits like grapes and mangoes, and green tea for preventing and treating this oral disease.

\section{Dietary Polyphenols and Periodontitis: Human Clinical Studies}

For many years, the role of dietary nutrients in oral health has been largely studied from the perspectives of macronutrients such as sugars that can promote dental caries and the growth of microorganisms. Increased sugar and total carbohydrate intake have been associated with an increased risk for developing dental caries and experiencing gingival bleeding [41]. Sugar acts to diminish oral health through fermentative metabolism of many oral bacteria, which results in the release of acidic byproducts that dissolve the mineral content of the teeth [4]. Yet, lactose has been observed to be less cariogenic than other sugars [4]. An analysis of NHANES III (1984-1994) data of young adults demonstrated that a high frequency of consumption of added sugars was associated with a greater prevalence of periodontal disease [42]. Therefore, it is important to consider the influence of dietary sugars for the development and severity of periodontitis even in conjunction with dietary polyphenols.

Clinical studies have also been conducted to determine the potential antimicrobial, antioxidant, and anti-inflammatory properties of dietary polyphenols (Table 2). A clinical study administering freshly-squeezed pomegranate juice as a mouth rinse in subjects without periodontal disease demonstrated significant reductions in the colony-forming units (CFUs) of Lactobacillus and Streptococcus species [43]. Pomegranates are rich in polyphenols, tannins, ellagic acid, and anthocyanins, which may be implicated in the antimicrobial properties of this mouth rinse. In another clinical study of patients with chronic periodontitis, a gel containing 1\% curcumin, which is the bioactive substance found in turmeric, was applied to affected areas in the periodontal pockets and resulted in significant bactericidal effects on P. gingivalis, P. intermedia, F. nucleatum, and Capnocytophaga [44]. Other clinical studies have demonstrated beneficial effects of dietary polyphenols on the clinical measurement of periodontal disease including probing depth (PD), gingival index (GI), and clinical attachment level (CAL), which are indicators of periodontitis severity. In one such study, supplementation with a capsule containing selected dehydrated fruits and vegetables was shown to significantly reduce PD compared with placebo pills [45]. In another study, sub-gingival application of a gel containing Emblica officinalis or gooseberry extract $(10 \%)$ showed reductions in PD, an increase in CAL, and improvements in the modified sulcus bleeding index [46]. A similar study of intra-pocket application of a green tea extract gel was demonstrated to decrease PD, GI, and relative CAL (rCAL) in chronic periodontitis patients [47]. Lastly, dietary polyphenols have been shown to possess significant anti-inflammatory and antioxidant properties. In a study of chronic periodontitis, patients were treated with either a green tea dentifrice containing $60 \%$ to $90 \%$ epigallocatechin or a standard fluoride/triclosan dentifrice. It was found that the green tea treatment significantly increased the activity of glutathione-S-transferase, which is an endogenous antioxidant, and this treatment subsequently decreased the degree of gingival inflammation [48]. 
Another study using dark chocolate, which is rich in cocoa flavonoids, demonstrated that dark chocolate increases total antioxidant capacity and decreases lipid peroxidation and the modified papillary bleeding index when compared with a white chocolate treatment group [49]. While these clinical findings as presented in Table 2 look promising for the management of periodontitis, it is important to consider the lack of characterization and standardization of polyphenol content in foods and beverages that may be associated with differential outcomes in humans. Nevertheless, based on the findings of these clinical studies, increasing oral exposure to dietary polyphenols with a concomitant decrease in sugar intake may be considered a prudent dietary strategy in managing periodontitis.

\section{Food vs. Purified Polyphenols in Periodontitis}

The source of polyphenols must be taken into consideration when interpreting their effects on the outcomes of periodontitis. Commonly consumed dietary polyphenols derived from food and beverages such as green tea [28,48], blueberry [27] and cranberry extracts [50], and pomegranate juice [43] have been shown to inhibit the growth of bacterial biofilms and inflammation and improve clinical outcomes of periodontitis. Green tea is a rich source of several flavonoids especially the gallated catechins [51]. Blueberries are high in anthocyanidins and phenolic acids [52] and cranberries offer proanthocyanidins (PACs) that have been associated with multiple anti-microbial effects [53]. PACs are a class of phenolic compounds that take the form of oligomers or polymers of polyhydroxy flavan-3-ol units such as (+)-catechin and (-)-epicatechin [54]. Pomegranate juice, which is a rich source of tannins, ellagic acid, and anthocyanins, has been shown to exert the highest antioxidant potential among the commonly consumed beverages among US consumers [55]. It also includes observed anti-microbial effects following a mouth rinse [43]. In addition to these sources of food, individual polyphenols such as curcumin [34], epigallocatechin gallate [33], myricetin [37], and mangiferin [38], which represent predominant polyphenols in turmeric, green tea, leafy vegetables, and mangos, respectively, have been mostly shown to decrease inflammation in experimental models of periodontitis. Overall, it appears that the natural combination of polyphenols in extracts from whole foods and beverages exert multi-factorial protective effects compared to isolated polyphenol supplements in periodontitis.

\section{Conclusions and Recommendations}

Periodontitis is a local inflammatory disease of the oral cavity associated with an increased risk for developing CVD, diabetes, and other chronic diseases, which highlights the urgent need to identify cost-effective population-level strategies for periodontitis prevention and treatment. Current data from cell biology and animal models and human clinical studies have demonstrated that selected dietary polyphenols have important antimicrobial, antioxidant, and anti-inflammatory properties resulting in improved clinical markers in periodontitis (Table 4 and Figure 1,). Dietary polyphenols are derived from a variety of sources such as curcumin in the commonly consumed turmeric and quercetin and catechins in green tea, fruits, and vegetables. Dietary polyphenols have been shown to effectively ameliorate gingival bleeding as well as alveolar bone loss in animals and human clinical studies by suppressing osteoclastogenesis and inhibiting inflammatory cytokines. While data from molecular studies are promising, further research is needed to learn about the effects of polyphenols for prevention and treatment of periodontal disease. The oral cavity, which is the first port of entry for foods andbeverages, is susceptible to their immediate local actions including detrimental effects that contribute to periodontitis. Therefore, the selection of polyphenols at each meal or snack in combination with adequate measures of standard oral hygiene care may play an important role in the prevention of periodontitis as well as other chronic inflammatory conditions that comprise this constellation of co-morbid conditions. 
Table 1. Polyphenols as antioxidant/anti-inflammatory/antimicrobial agents in periodontitis: experimental cellular models.

\begin{tabular}{|c|c|c|c|}
\hline Study Design and Model & Polyphenol & Significant Findings & Author, Year \\
\hline $\begin{array}{l}\text { HPLC culture stimulated with LPS } \\
\text { of } P \text {. gingivalis }\end{array}$ & Resveratrol $(25,50$, and $100 \mu \mathrm{M})$ & $\begin{array}{l}\downarrow \text { NO expression by } P \text {. gingivalis in a } \\
\text { dose-dependent and time-dependent manner }\end{array}$ & Rizzo et al., 2012 [32] \\
\hline $\begin{array}{l}\text { F. nucleatum cultures in } \\
\text { Todd-Hewitt broth }\end{array}$ & $\begin{array}{l}70 \% \text { ethanolic blueberry extract of varying } \\
\text { concentrations }(500,250,125,62.5,31.25,15.62 \text {, } \\
\text { and } 7.9 \mu \mathrm{g} / \mathrm{mL})\end{array}$ & $\downarrow$ growth of $F$. nucleatum and biofilm formation & Ben Lagha et al., 2015 [27] \\
\hline $\begin{array}{l}\text { Human gingival epithelial cells } \\
\text { grown in keratinocyte medium }\end{array}$ & $\begin{array}{l}\text { EGCG }(1 \text { and } 5 \mathrm{mg} / \mathrm{mL}) \& \text { AC-PCs }(25 \text { and } \\
50 \mathrm{mg} / \mathrm{mL})\end{array}$ & $\downarrow$ release of several inflammatory cytokines & Lombardo et al., 2015 [29] \\
\hline $\begin{array}{l}\text { P. gingivalis culture in sheep } \\
\text { blood agar }\end{array}$ & $\begin{array}{l}\text { RA1 }(1-100 \mu \mathrm{g} / \mathrm{mL}) \text { containing flavan-3-ols, } \\
\text { flavonoids, and oligomeric proantho cyanidins }\end{array}$ & $\begin{array}{l}\downarrow \text { adhesion of } P \text {. gingivalis to human KB cells due to } \\
\text { the specific activity of galloylated oligomeric } \\
\text { proanthocyanidins, inhibited gingipain activity, and } \\
\text { inhibited } P \text {. gingivalis-induced hem agglutination }\end{array}$ & Schmuch et al., 2015 [30] \\
\hline $\begin{array}{l}\text { Bacterial cultures of } S \text {. mitis, } A \\
\text { actinomycetemcomitans, P. gingivalis, } \\
\text { and F. nucleatum }\end{array}$ & $\begin{array}{l}\text { Phenols and polyphenols from different classes } \\
\text { including hydroxyl acids, flavanols, flavanones, } \\
\text { anthocyanins, and phenolics }(0.24-2500 \mu \mathrm{g} / \mathrm{mL} \text {, } \\
\text { depending on the compound) }\end{array}$ & $\begin{array}{l}\downarrow \text { planktonic growth, mostly by curcumin which } \\
\text { was followed by pyrogallol, pyrocatechol, } \\
\text { and quercetin }\end{array}$ & Shahzad et al., 2015 [26] \\
\hline $\begin{array}{l}\text { Normal human fibroblasts } \\
\text { incubated with HSA, G-HSA, or } \\
\text { P. gingivalis LPS }\end{array}$ & $\begin{array}{l}\text { Cranberry high molecular weight NDM } \\
(10-50 \mu \mathrm{g} / \mathrm{mL} \text { with HSA or G-HSA alone; } 50 \text { or } \\
100 \mu \mathrm{g} / \mathrm{mL} \text { with HSA, G-HSA, and LPS })\end{array}$ & $\downarrow$ production of IL-6 and MMP-3 & Tipton et al., 2016 [50] \\
\hline $\begin{array}{l}P \text {. gingivalis strain cultivated in agar } \\
\text { medium and broth }\end{array}$ & $\begin{array}{l}\text { L. brasiliense extract in water/acetone solution } \\
(50-500 \mu \mathrm{g} / \mathrm{mL})\end{array}$ & $\begin{array}{l}\downarrow \text { adhesion of } P \text {. gingivalis to human KB cells and } \\
\text { the activity of Arg-gingipain }\end{array}$ & De Oliveira et al., 2017 [31] \\
\hline F. nucleatum in Todd-Hewitt broth & $\begin{array}{l}\text { Green tea }(20 \mathrm{mg}) \text {, black tea }(10 \mathrm{mg}) \text {, and } \\
\text { theaflavins }(20 \mathrm{mg}) \text { in solution }\end{array}$ & $\downarrow$ biofilm formation & Ben Lagha et al., 2017 [28] \\
\hline
\end{tabular}

AC-PC, A-type cranberry proanthocyanidins, EGCG, epigallocatechin gallate, G-HSA, glycated human serum albumin, HSA, human serum albumin, HPLC, human periodontal ligament cell, IL-6, interleukin-6; LPS, lipopolysaccharide, MMP-3, matrix metalloproteinase-3, NDM, non-dialyzable material, NO, nitric oxide; RA1, Rumex acetosa (common sorrel) extract. Symbol: downward arrow, decrease. 
Table 2. Polyphenols as antioxidant/anti-inflammatory/antimicrobial agents in periodontitis: clinical studies.

\begin{tabular}{|c|c|c|c|}
\hline Study Design and Model & Polyphenol & Significant Findings & Author, Year \\
\hline $\begin{array}{l}\text { Pre-post intervention, healthy } \\
\text { volunteers ( } n=30 \text {; age } 25-30 \text { years) }\end{array}$ & $\begin{array}{l}\text { Pomegranate juice }(30 \mathrm{~mL}) \text { mouth rinse for } \\
2 \mathrm{~min}\end{array}$ & $\downarrow$ CFUs of both Streptococci and Lactobacillus spp. & Kote et al., 2011 [43] \\
\hline $\begin{array}{l}\text { Crossover RCT, patients with chronic } \\
\text { periodontitis ( } n=60 \text {, age } 30-60 \text { years) }\end{array}$ & $\begin{array}{l}\text { Daily oral intake of } 6 \text { FV capsules, } 6 \text { FVB } \\
\text { capsules, or placebo capsules for } 2 \text { months }\end{array}$ & $\downarrow$ PPD in FV compared with placebo & Chapple et al., 2012 [45] \\
\hline $\begin{array}{l}\text { Patients with chronic periodontitis } \\
(n=30 \text {; age } 38.9-10.67 \text { years })\end{array}$ & $\begin{array}{l}\text { Sustained-release green tea extract gel }(1 \%) \\
\text { containing ECGC administered once }\end{array}$ & $\downarrow$ GI, $\mathrm{PD}$, and $\mathrm{rCAL}$ & Chava \& Vedula, 2013 [47] \\
\hline $\begin{array}{l}\text { Patients with chronic periodontitis } \\
(n=25 ; \text { age } 21-45 \text { years) }\end{array}$ & $\begin{array}{l}1 \% \text { curcumin gel inserted into periodontal } \\
\text { pockets with blunt syringe at intervals of } 1,3 \text {, } \\
\text { and } 6 \text { months following the start of the study }\end{array}$ & $\begin{array}{l}\downarrow \text { Bacterial counts of P. gingivalis, P. intermedia, } \\
\text { F. nucleatum, and Capnocytophaga spp. }\end{array}$ & Bhatia et al., 2014 [44] \\
\hline $\begin{array}{l}\text { Crossover RCT; patients with } \\
\text { moderate chronic periodontitis } \\
(n=40, \text { age } 30-50 \text { years })\end{array}$ & $\begin{array}{l}\text { Oral intake } 3 \text { times a day for } 4 \text { weeks of } 30 \mathrm{~g} \\
\text { dark chocolate with } 78 \% \text { cacao (containing } \\
\text { flavonoids such as catechin and procyanidins) } \\
\text { or white chocolate placebo } w / o \text { cacao }\end{array}$ & $\downarrow$ MPBI and lipid peroxidation & Roodgaryan et al., 2015 [49] \\
\hline $\begin{array}{l}\text { Patients treated with root planning } \\
\text { and scaling }(n=40, \text { age } \geq 30 \text { years })\end{array}$ & $\begin{array}{l}10 \% \text { E. officinalis extract gel administered } \\
\text { subgingivally once and parameters measured } 2 \\
\text { and } 3 \text { months post-treatment }\end{array}$ & $\downarrow$ Inflammation, mSBI and PPD & Grover et al., 2016 [46] \\
\hline $\begin{array}{l}\text { Patients with mild to moderate } \\
\text { periodontitis ( } n=30 \text {, age 18-60 years) }\end{array}$ & $\begin{array}{l}\text { Green tea extract dentifrice with } 60-90 \% \text { EGCG } \\
\text { or placebo dentifrice with fluoride and triclosan, } \\
\text { brushed onto teeth for } 2-5 \text { min daily for } 4 \text { weeks }\end{array}$ & $\downarrow$ gingival inflammation & Hrishi et al., 2016 [48] \\
\hline
\end{tabular}

CAL, clinical attachment level, CFUs, colony-forming units, EGCG, epigallocatechin gallate; FV, fruit/vegetable-containing capsules, FVB, fruit/vegetable/berry-containing capsules, GI, gingival index, GST, glutathione-S-transferase, MPBI, modified papillary bleeding index, mSBI, modified sulcus bleeding index, PD, probing depth, PPD, probing pocket depth, rCAL, relative clinical attachment level, RCT, randomized clinical trial, TAC, total antioxidant capacity. Symbol: downward arrow, decrease. 
Table 3. Polyphenols as antioxidant/anti-inflammatory/antimicrobial agents in periodontitis: experimental animal models.

\begin{tabular}{|c|c|c|c|}
\hline Study Design and Model & Polyphenol & Significant Findings & Author, Year \\
\hline Adult male Sprague-Dawley rats & $\begin{array}{l}\text { Hypericum perforatum extract ( } 2 \mathrm{mg} / \mathrm{kg} / \text { day }) \\
\text { administered orally }\end{array}$ & $\begin{array}{l}\downarrow \text { gingivomucosal tissue injury, alveolar bone } \\
\text { loss, \& expression of NF-kB p65 }\end{array}$ & Paterniti et al., 2010 [35] \\
\hline $\begin{array}{l}\text { E. coli-induced periodontitis in } \\
\text { Lewis rats }\end{array}$ & $\begin{array}{l}\text { Sunphenon BG blend ( } 91.3 \% \text { polyphenols) } \\
\text { administered topically to affected periodontal areas }\end{array}$ & $\downarrow$ periodontal detachment and bone resorption & Yoshinaga et al., 2014 [36] \\
\hline $\begin{array}{l}\text { P. gingivalis induced periodontitis } \\
\text { in BALB/c mice }\end{array}$ & $\begin{array}{l}\text { EGCG }(0.02 \%) \text { or vehicle (distilled water) in } \\
\text { drinking water }\end{array}$ & $\downarrow$ inflammation e.g., IL-17, IL-1 $\beta$ vs. vehicle & Cai et al., 2015 [33] \\
\hline $\begin{array}{l}\text { Ligation-induced periodontitis in } \\
\text { Wistar rats }\end{array}$ & $\begin{array}{l}\text { Hawthorn (Crataeus orientalis M Bieber) extract (100 } \\
\mathrm{mg} / \mathrm{kg} \text { ) vs saline administered orogastrically }\end{array}$ & $\begin{array}{l}\downarrow \text { osteoclast activity and subsequently } \\
\text { ameliorated alveolar bone loss induced } \\
\text { by periodontitis }\end{array}$ & Hatipoğlu et al., 2015 [55] \\
\hline $\begin{array}{l}\text { C57BL/J6 ovariectomized } \\
\text { female mice }\end{array}$ & $\begin{array}{l}\text { Low or high dose ( } 2 \text { or } 5 \mathrm{mg} / \mathrm{kg} / \text { day) of myricetin, } \\
\text { which is a polyphenol derived from fruits and } \\
\text { vegetables, administered intraperitoneally } \\
\text { vs. placebo }\end{array}$ & $\begin{array}{l}\downarrow \text { alveolar bone loss by inhibiting } \\
\text { osteoclastogenesis induced by periodontitis }\end{array}$ & Huang et al., 2016 [37] \\
\hline Wistar rats & $\begin{array}{l}\text { Curcumin }(100 \mathrm{mg} / \mathrm{kg}) \text {, resveratrol }(10 \mathrm{mg} / \mathrm{kg}) \text {, } \\
\text { curcumin + resveratrol or resveratrol alone } \\
\text { administered orogastrically }\end{array}$ & $\downarrow$ gingival IL-1 $\beta$ in curcumin+resveratrol & Corrêa et al., 2017 [34] \\
\hline $\begin{array}{l}\text { P. gingivalis induced periodontitis } \\
\text { in male C57BL/6J wild-type mice }\end{array}$ & Mangiferin $(50 \mathrm{mg} / \mathrm{kg})$ oral application & $\begin{array}{l}\downarrow \text { TNF- } \alpha \text { production, phosphorylation in the } \\
\text { NF- } \mathrm{B} \text { and JK-1 signal pathways, and alveolar } \\
\text { bone loss }\end{array}$ & Li et al., 2017 [38] \\
\hline
\end{tabular}


Table 4. Summary of mechanisms of action of dietary polyphenols in periodontitis.

\begin{tabular}{|c|c|}
\hline Polyphenol & Mechanisms of Action \\
\hline Resveratrol & $\begin{array}{l}\text { Reduces NO expression by } P \text {. gingivalis bacteria by inhibiting inflammatory cytokines and improving viability of } \\
\text { affected HPLCs [32] }\end{array}$ \\
\hline $\begin{array}{l}\text { Blueberry flavonoids, phenolic acids, and procyanidins } \\
\text { e.g., chlorogenic acid, ellagic acid, quercetin, } \\
\text { anthocyanins, and proanthocyanidins }\end{array}$ & $\begin{array}{l}\text { Reduce bacterial growth and biofilm formation via antibacterial, inhibitory effects against Gram-negative bacteria } \\
\text { such as F. nucleatum }[26,27,30]\end{array}$ \\
\hline EGCG & $\begin{array}{l}\text { Inhibits release of inflammatory cytokines (IL-17, IL-1 } \beta \text { ) by modulating gene expression pathways (e.g., NF- } \mathrm{kB} \text { ), } \\
\text { and decreasing inflammation/oxidation by increasing the activity of GST }[33,48]\end{array}$ \\
\hline RA1 & Inhibit adhesion of bacteria through a specific activity of galloylated oligomeric proanthocyanidins [30] \\
\hline Curcumin & Inhibits planktonic growth by decreasing metabolic activity of bacterial species [44] \\
\hline Curcumin + Resveratrol & $\begin{array}{l}\text { Reduces gingival IL-1 } \beta \text { and inhibits NF- } \mathrm{kB} \text {, which lowers proteasome activity and resulting cell damage and } \\
\text { inflammation [34] }\end{array}$ \\
\hline Pyrogallol & Inhibits planktonic growth by reducing biomass of planktonic films [26] \\
\hline Pyrocatechol & Inhibits planktonic growth by reducing biomass of planktonic films [26] \\
\hline Quercetin & Inhibits planktonic growth by reducing biomass of planktonic films [26] \\
\hline Cranberry flavonoids and proanthocyanidins & Inhibit IL-6 production and MMP-3 by suppressing the NF- $\mathrm{kB}$ and MAPK/AP-1 signaling pathways [50] \\
\hline L. brasiliense flavan-3-ols and proanthocyanidins & Reduce adhesion of $P$. gingivalis to human KB cells by inhibiting Arg-gingipain activity $[30,31]$ \\
\hline Tea polyphenols e.g., theaflavins & $\begin{array}{l}\text { Inhibit biofilm formation and adhesion of pathogens to the oral mucosa likely by binding to receptors in the } \\
\text { bacterial cell wall }[27,28]\end{array}$ \\
\hline Hypericum perforatum flavonoids and phenolic acids & $\begin{array}{l}\text { Inhibits inflammatory cytokine production by suppressing NF- } \mathrm{kB} \text { p65 pathway and reducing NO expression by } \\
\text { pathogenic bacteria through the suppression of the iNOS system [35] }\end{array}$ \\
\hline Myricetin & Reduces alveolar bone loss by inhibiting osteoclastogenesis [37] \\
\hline Mangiferin & $\begin{array}{l}\text { Suppresses TNF-alpha production and inhibits phosphorylation of NF- } \mathrm{KB} \text { and JK-1 pathways, which inhibits } \\
\text { production of inflammatory cytokines and alleviates tissue injury [38] }\end{array}$ \\
\hline Pomegranate phenolic compounds & Reduces number of pathogenic Streptococci and Lactobacilli pathogens and inhibits the formation of colony units [43] \\
\hline Cacao flavonoids & Decrease lipid peroxidation and improve gingival bleeding [49] \\
\hline E. officinalis flavonoids, phenols, and tannins & $\begin{array}{l}\text { May reduce inflammation by suppressing the action of histamine, serotonin, prostaglandins, and other } \\
\text { inflammatory mediators [46] }\end{array}$ \\
\hline
\end{tabular}

AP-1, activator protein-1, EGCG, epigallocatechin gallate, GST, glutathione-S-transferase, HPLC, human periodontal ligament cell, IL-1 $\beta$, interleukin-1 $\beta$, IL-6, interleukin-6, IL-17, interleukin-17, iNOS, inducible nitric oxide synthase, JK-1, Janus-kinase 1 pathway, MAPK, mitogen-activated protein kinases, MMP-3, matrix metalloproteinase-3, NF- $\mathrm{B}$, nuclear factor- $\mathrm{kB}, \mathrm{NO}$, nitric oxide, RA1, rumex acetosa extract (polyphenol), TNF-alpha, tumor necrosis factor-alpha. 


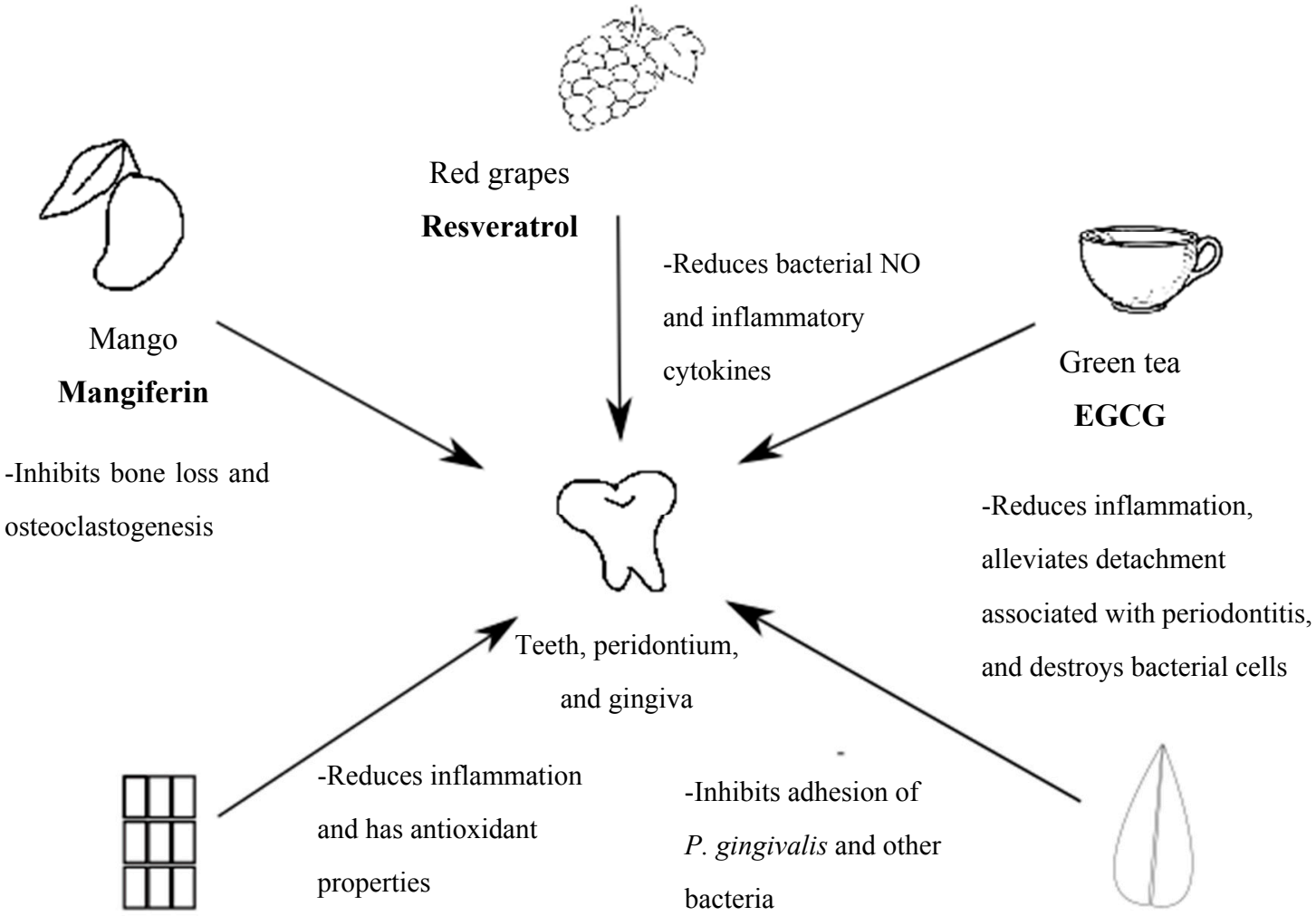

Dark chocolate

Cocoa phenols

Sorrel

\section{RA1}

Figure 1. Overview of the role of dietary polyphenols in the management of periodontitis.

Author Contributions: Conceptualization, A.B. and J.L.E.; Methodology, A.B.; Writing-Original Draft Preparation, A.B.; Writing-Review \& Editing, A.B., E.M. and J.L.E.; Visualization, A.B.; Supervision, J.L.E.; Project Administration, A.B.

Funding: This research received no external funding. The APC was funded by the School of Allied Health Sciences at UNLV.

Acknowledgments: We acknowledge the support of faculty and staff at the School of Allied Health Sciences and the School of Dental Medicine at UNLV in this collaboration.

Conflicts of Interest: The authors declare no conflicts of interest.

\section{References}

1. Eke, P.I.; Dye, B.A.; Wei, L.; Slade, G.D.; Thornton-Evans, G.O.; Borgnakke, W.S.; Taylor, G.W.; Page, R.C.; Beck, J.D.; Genco, R.J. Update on prevalence of periodontitis in adults in the United States: Nhanes 2009 to 2012. J. Periodontol. 2015, 86, 611-622. [CrossRef] [PubMed]

2. Page, R.C.; Eke, P.I. Case definitions for use in population-based surveillance of periodontitis. J. Periodontol. 2007, 78, 1387-1399. [CrossRef] [PubMed]

3. Kassebaum, N.J.; Bernabe, E.; Dahiya, M.; Bhandari, B.; Murray, C.J.; Marcenes, W. Global burden of severe periodontitis in 1990-2010: A systematic review and meta-regression. J. Dent. Res. 2014, 93, 1045-1053. [CrossRef] [PubMed]

4. Najeeb, S.; Zafar, M.S.; Khurshid, Z.; Zohaib, S.; Almas, K. The role of nutrition in periodontal health: An update. Nutrients 2016, 8, 530. [CrossRef] [PubMed] 
5. Humphrey, L.L.; Fu, R.; Buckley, D.I.; Freeman, M.; Helfand, M. Periodontal disease and coronary heart disease incidence: A systematic review and meta-analysis. J. Gen. Intern. Med. 2008, 23, 2079-2086. [CrossRef] [PubMed]

6. Spahr, A.; Klein, E.; Khuseyinova, N.; Boeckh, C.; Muche, R.; Kunze, M.; Rothenbacher, D.; Pezeshki, G.; Hoffmeister, A.; Koenig, W. Periodontal infections and coronary heart disease: Role of periodontal bacteria and importance of total pathogen burden in the coronary event and periodontal disease (corodont) study. Arch. Intern. Med. 2006, 166, 554-559. [CrossRef] [PubMed]

7. Preshaw, P.M.; Alba, A.L.; Herrera, D.; Jepsen, S.; Konstantinidis, A.; Makrilakis, K.; Taylor, R. Periodontitis and diabetes: A two-way relationship. Diabetologia 2012, 55, 21-31. [CrossRef] [PubMed]

8. Leong, X.F.; Ng, C.Y.; Badiah, B.; Das, S. Association between hypertension and periodontitis: Possible mechanisms. Sci. World J. 2014, 2014, 768237. [CrossRef] [PubMed]

9. Morozumi, T.; Yashima, A.; Gomi, K.; Ujiie, Y.; Izumi, Y.; Akizuki, T.; Mizutani, K.; Takamatsu, H.; Minabe, M.; Miyauchi, S.; et al. Increased systemic levels of inflammatory mediators following one-stage full-mouth scaling and root planing. J. Period. Res. 2018. [CrossRef] [PubMed]

10. Ebersole, J.L.; Kirakodu, S.; Novak, M.J.; Stromberg, A.J.; Shen, S.; Orraca, L.; Gonzalez-Martinez, J.; Burgos, A.; Gonzalez, O.A. Cytokine gene expression profiles during initiation, progression and resolution of periodontitis. J. Clin. Periodontol. 2014, 41, 853-861. [CrossRef] [PubMed]

11. Nanri, H.; Yamada, Y.; Itoi, A.; Yamagata, E.; Watanabe, Y.; Yoshida, T.; Miyake, M.; Date, H.; Ishikawa-Takata, K.; Yoshida, M.; et al. Frequency of fruit and vegetable consumption and the oral health-related quality of life among japanese elderly: A cross-sectional study from the kyoto-kameoka study. Nutrients 2017, 9, 1362. [CrossRef] [PubMed]

12. Chapple, I.L.; Bouchard, P.; Cagetti, M.G.; Campus, G.; Carra, M.C.; Cocco, F.; Nibali, L.; Hujoel, P.; Laine, M.L.; Lingstrom, P.; et al. Interaction of lifestyle, behaviour or systemic diseases with dental caries and periodontal diseases: Consensus report of group 2 of the joint efp/orca workshop on the boundaries between caries and periodontal diseases. J. Clin. Periodontol. 2017, 44, S39-S51. [CrossRef] [PubMed]

13. Chapple, I.L. Potential mechanisms underpinning the nutritional modulation of periodontal inflammation. J. Am. Dent. Assoc. (1939) 2009, 140, 178-184. [CrossRef]

14. Kondo, K.; Ishikado, A.; Morino, K.; Nishio, Y.; Ugi, S.; Kajiwara, S.; Kurihara, M.; Iwakawa, H.; Nakao, K.; Uesaki, S.; et al. A high-fiber, low-fat diet improves periodontal disease markers in high-risk subjects: A pilot study. Nutr. Res. (New York) 2014, 34, 491-498. [CrossRef] [PubMed]

15. Sakagami, H.; Tomomura, M. Dental application of natural products. Medicines (Basel) 2018, 5, 21. [CrossRef] [PubMed]

16. Knaze, V.; Rothwell, J.A.; Zamora-Ros, R.; Moskal, A.; Kyro, C.; Jakszyn, P.; Skeie, G.; Weiderpass, E.; Santucci de Magistris, M.; Agnoli, C.; et al. A new food-composition database for 437 polyphenols in 19,899 raw and prepared foods used to estimate polyphenol intakes in adults from 10 European countries. Am. J. Clin. Nutr. 2018. [CrossRef] [PubMed]

17. Vetrani, C.; Vitale, M.; Bozzetto, L.; Della Pepa, G.; Cocozza, S.; Costabile, G.; Mangione, A.; Cipriano, P.; Annuzzi, G.; Rivellese, A.A. Association between different dietary polyphenol subclasses and the improvement in cardiometabolic risk factors: Evidence from a randomized controlled clinical trial. Acta Diabetol. 2018, 55, 149-153. [CrossRef] [PubMed]

18. Cassidy, A.; Mukamal, K.J.; Liu, L.; Franz, M.; Eliassen, A.H.; Rimm, E.B. High anthocyanin intake is associated with a reduced risk of myocardial infarction in young and middle-aged women. Circulation 2013, 127, 188-196. [CrossRef] [PubMed]

19. Gao, X.; Cassidy, A.; Schwarzschild, M.A.; Rimm, E.B.; Ascherio, A. Habitual intake of dietary flavonoids and risk of parkinson disease. Neurology 2012, 78, 1138-1145. [CrossRef] [PubMed]

20. Wedick, N.M.; Pan, A.; Cassidy, A.; Rimm, E.B.; Sampson, L.; Rosner, B.; Willett, W.; Hu, F.B.; Sun, Q.; van Dam, R.M. Dietary flavonoid intakes and risk of type 2 diabetes in us men and women. Am. J. Clin. Nutr. 2012, 95, 925-933. [CrossRef] [PubMed]

21. Zhao, H.; Zhu, W.; Jia, L.; Sun, X.; Chen, G.; Zhao, X.; Li, X.; Meng, X.; Kong, L.; Xing, L.; et al. Phase i study of topical epigallocatechin-3-gallate (EGCG) in patients with breast cancer receiving adjuvant radiotherapy. Br. J. Radiol. 2016, 89, 20150665. [CrossRef] [PubMed] 
22. Ryden, L.; Buhlin, K.; Ekstrand, E.; de Faire, U.; Gustafsson, A.; Holmer, J.; Kjellstrom, B.; Lindahl, B.; Norhammar, A.; Nygren, A.; et al. Periodontitis increases the risk of a first myocardial infarction: A report from the parokrank study. Circulation 2016, 133, 576-583. [PubMed]

23. Chapple, I.L.; Genco, R. Diabetes and periodontal diseases: Consensus report of the joint efp/aap workshop on periodontitis and systemic diseases. J. Periodontol. 2013, 84, S106-S112. [CrossRef] [PubMed]

24. Hirasawa, M.; Takada, K.; Makimura, M.; Otake, S. Improvement of periodontal status by green tea catechin using a local delivery system: A clinical pilot study. J. Period. Res. 2002, 37, 433-438. [CrossRef]

25. Shahzad, M.; Millhouse, E.; Culshaw, S.; Edwards, C.A.; Ramage, G.; Combet, E. Selected dietary (poly)phenols inhibit periodontal pathogen growth and biofilm formation. Food Function 2015, 6, 719-729. [CrossRef] [PubMed]

26. Ben Lagha, A.; Dudonne, S.; Desjardins, Y.; Grenier, D. Wild blueberry (vaccinium angustifolium ait.) polyphenols target fusobacterium nucleatum and the host inflammatory response: Potential innovative molecules for treating periodontal diseases. J. Agric. Food Chem. 2015, 63, 6999-7008. [CrossRef] [PubMed]

27. Ben Lagha, A.; Haas, B.; Grenier, D. Tea polyphenols inhibit the growth and virulence properties of fusobacterium nucleatum. Sci. Rep. 2017, 7, 44815. [CrossRef] [PubMed]

28. Schmuch, J.; Beckert, S.; Brandt, S.; Lohr, G.; Hermann, F.; Schmidt, T.J.; Beikler, T.; Hensel, A. Extract from rumex acetosa 1. For prophylaxis of periodontitis: Inhibition of bacterial in vitro adhesion and of gingipains of porphyromonas gingivalis by epicatechin-3-O-(4beta->8)-epicatechin-3-O-gallate (procyanidin-B2-Di-gallate). PLoS ONE 2015, 10, e0120130. [CrossRef] [PubMed]

29. de Oliveira Caleare, A.; Hensel, A.; Mello, J.C.; Pinha, A.B.; Panizzon, G.P.; Lechtenberg, M.; Petereit, F.; Nakamura, C.V. Flavan-3-ols and proanthocyanidins from limonium brasiliense inhibit the adhesion of porphyromonas gingivalis to epithelial host cells by interaction with gingipains. Fitoterapia 2017, 118, 87-93. [CrossRef] [PubMed]

30. Lombardo Bedran, T.B.; Palomari Spolidorio, D.; Grenier, D. Green tea polyphenol epigallocatechin-3-gallate and cranberry proanthocyanidins act in synergy with cathelicidin (ll-37) to reduce the lps-induced inflammatory response in a three-dimensional co-culture model of gingival epithelial cells and fibroblasts. Arch. Oral Biol. 2015, 60, 845-853. [CrossRef] [PubMed]

31. Rizzo, A.; Bevilacqua, N.; Guida, L.; Annunziata, M.; Romano Carratelli, C.; Paolillo, R. Effect of resveratrol and modulation of cytokine production on human periodontal ligament cells. Cytokine 2012, 60, 197-204. [CrossRef] [PubMed]

32. Cai, Y.; Chen, Z.; Liu, H.; Xuan, Y.; Wang, X.; Luan, Q. Green tea epigallocatechin-3-gallate alleviates porphyromonas gingivalis-induced periodontitis in mice. Int. Immunopharmacol. 2015, 29, 839-845. [CrossRef] [PubMed]

33. Correa, M.G.; Pires, P.R.; Ribeiro, F.V.; Pimentel, S.Z.; Casarin, R.C.; Cirano, F.R.; Tenenbaum, H.T.; Casati, M.Z. Systemic treatment with resveratrol and/or curcumin reduces the progression of experimental periodontitis in rats. J. Period. Res. 2017, 52, 201-209. [CrossRef] [PubMed]

34. Paterniti, I.; Briguglio, E.; Mazzon, E.; Galuppo, M.; Oteri, G.; Cordasco, G.; Cuzzocrea, S. Effects of hypericum perforatum, in a rodent model of periodontitis. BMC Complement. Altern. Med. 2010, 10, 73. [CrossRef] [PubMed]

35. Yoshinaga, Y.; Ukai, T.; Nakatsu, S.; Kuramoto, A.; Nagano, F.; Yoshinaga, M.; Montenegro, J.L.; Shiraishi, C.; Hara, Y. Green tea extract inhibits the onset of periodontal destruction in rat experimental periodontitis. J. Period. Res. 2014, 49, 652-659. [CrossRef]

36. Huang, J.; Wu, C.; Tian, B.; Zhou, X.; Ma, N.; Qian, Y. Myricetin prevents alveolar bone loss in an experimental ovariectomized mouse model of periodontitis. Int. J. Mol. Sci. 2016, 17, 422. [CrossRef] [PubMed]

37. Li, H.; Wang, Q.; Ding, Y.; Bao, C.; Li, W. Mangiferin ameliorates porphyromonas gingivalis-induced experimental periodontitis by inhibiting phosphorylation of nuclear factor-kappab and janus kinase 1-signal transducer and activator of transcription signaling pathways. J. Period. Res. 2017, 52, 1-7. [CrossRef] [PubMed]

38. Erlund, I.; Marniemi, J.; Hakala, P.; Alfthan, G.; Meririnne, E.; Aro, A. Consumption of black currants, lingonberries and bilberries increases serum quercetin concentrations. Eur. J. Clin. Nutr. 2003, 57, 37-42. [CrossRef] [PubMed] 
39. Cheng, A.L.; Hsu, C.H.; Lin, J.K.; Hsu, M.M.; Ho, Y.F.; Shen, T.S.; Ko, J.Y.; Lin, J.T.; Lin, B.R.; Ming-Shiang, W.; et al. Phase I clinical trial of curcumin, a chemopreventive agent, in patients with high-risk or pre-malignant lesions. Anticancer Res. 2001, 21, 2895-2900. [PubMed]

40. Hujoel, P.P.; Lingstrom, P. Nutrition, dental caries and periodontal disease: A narrative review. J. Clin. Periodontol. 2017, 44, S79-S84. [CrossRef] [PubMed]

41. Lula, E.C.; Ribeiro, C.C.; Hugo, F.N.; Alves, C.M.; Silva, A.A. Added sugars and periodontal disease in young adults: An analysis of nhanes III data. Am. J. Clin. Nutr. 2014, 100, 1182-1187. [CrossRef] [PubMed]

42. Kote, S.; Kote, S.; Nagesh, L. Effect of pomegranate juice on dental plaque microorganisms (streptococci and lactobacilli). Anc. Sci. Life 2011, 31, 49-51. [PubMed]

43. Bhatia, M.; Urolagin, S.S.; Pentyala, K.B.; Urolagin, S.B.; K, B.M.; Bhoi, S. Novel therapeutic approach for the treatment of periodontitis by curcumin. J. Clin. Diagn. Res. 2014, 8, ZC65-ZC69. [CrossRef] [PubMed]

44. Chapple, I.L.; Milward, M.R.; Ling-Mountford, N.; Weston, P.; Carter, K.; Askey, K.; Dallal, G.E.; De Spirt, S.; Sies, H.; Patel, D.; et al. Adjunctive daily supplementation with encapsulated fruit, vegetable and berry juice powder concentrates and clinical periodontal outcomes: A double-blind rct. J. Clin. Periodontol. 2012, 39, 62-72. [CrossRef] [PubMed]

45. Grover, S.; Tewari, S.; Sharma, R.K.; Singh, G.; Yadav, A.; Naula, S.C. Effect of subgingivally delivered 10\% emblica officinalis gel as an adjunct to scaling and root planing in the treatment of chronic periodontitis-A randomized placebo-controlled clinical trial. Phytother. Res. 2016, 30, 956-962. [CrossRef] [PubMed]

46. Chava, V.K.; Vedula, B.D. Thermo-reversible green tea catechin gel for local application in chronic periodontitis: A 4-week clinical trial. J. Periodontol. 2013, 84, 1290-1296. [CrossRef] [PubMed]

47. Hrishi, T.S.; Kundapur, P.P.; Naha, A.; Thomas, B.S.; Kamath, S.; Bhat, G.S. Effect of adjunctive use of green tea dentifrice in periodontitis patients-A randomized controlled pilot study. Int. J. Dent. Hyg. 2016, 14, 178-183. [CrossRef] [PubMed]

48. Roodgaryan, R.; Jenabian, N.; Moghadamnia, A.A.; Pouramir, M.; Khadir, F. Clinical and biochemical effects of dark chocolate in moderate chronic periodontitis. Casp. J. Dent. Res. 2015, 4, 43-49.

49. Tipton, D.A.; Hatten, A.A.; Babu, J.P.; Dabbous, M. Effect of glycated albumin and cranberry components on interleukin- 6 and matrix metalloproteinase-3 production by human gingival fibroblasts. J. Period. Res. 2016, 51, 228-236. [CrossRef] [PubMed]

50. Basu, A.; Lucas, E.A. Mechanisms and effects of green tea on cardiovascular health. Nutr. Rev. 2007, 65, 361-375. [CrossRef] [PubMed]

51. Michalska, A.; Lysiak, G. Bioactive compounds of blueberries: Post-harvest factors influencing the nutritional value of products. Int. J. Mol. Sci. 2015, 16, 18642-18663. [CrossRef] [PubMed]

52. Feghali, K.; Feldman, M.; La, V.D.; Santos, J.; Grenier, D. Cranberry proanthocyanidins: Natural weapons against periodontal diseases. J. Agric. Food Chem. 2012, 60, 5728-5735. [CrossRef] [PubMed]

53. Yamakoshi, J.; Saito, M.; Kataoka, S.; Kikuchi, M. Safety evaluation of proanthocyanidin-rich extract from grape seeds. Food Chem. Toxicol. Int. J. Publ. Br. Ind. Biol. Res. Assoc. 2002, 40, 599-607. [CrossRef]

54. Seeram, N.P.; Aviram, M.; Zhang, Y.; Henning, S.M.; Feng, L.; Dreher, M.; Heber, D. Comparison of antioxidant potency of commonly consumed polyphenol-rich beverages in the united states. J. Agric. Food Chem. 2008, 56, 1415-1422. [CrossRef] [PubMed]

55. Hatipoglu, M.; Saglam, M.; Koseoglu, S.; Koksal, E.; Keles, A.; Esen, H.H. The effectiveness of crataegus orientalis $\mathrm{m}$ bieber. (hawthorn) extract administration in preventing alveolar bone loss in rats with experimental periodontitis. PLoS ONE 2015, 10, e0128134. [CrossRef] [PubMed]

(C) 2018 by the authors. Licensee MDPI, Basel, Switzerland. This article is an open access article distributed under the terms and conditions of the Creative Commons Attribution (CC BY) license (http://creativecommons.org/licenses/by/4.0/). 